\title{
Reseach Paper: Development and Validation of a Well-being Scale Based on Nahj al-Balagha
}

\author{
Samira Mirzaei $^{1}$ (D), Samaneh Najarpourian ${ }^{1 *}$ (D), Ebrahim Na'imi² ${ }^{\text {DO }}$, Seyed Abdolvahab Samavi ${ }^{3}$ (D) \\ 1. Department of Counseling, Faculty of Humanities, University of Hormozgan, Bandar Abbas, Iran. \\ 2. Department of Counseling, Faculty of Psychology, Allameh Tabatabaei University, Tehran, Iran. \\ 3. Department of Educational Sciences, Faculty of Humanities, University of Hormozgan, Bandar Abbas, Iran
}

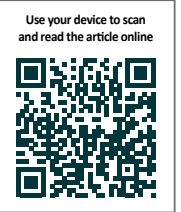

Citation Mirzaei S, Najarpourian S, Na'imi E, Samavi SA. Development and Validation of a Well-being Scale Based on Nahj al-Balagha . Journal of Research \& Health. 2020; 10(6):411-420. http://dx.doi.org/10.32598/JRH.10.6.1644.1

dol: : http://dx.doi.org/10.32598/JRH.10.6.1644.1

\section{(i) (8)}

Article info:

Received: 17 Jan 2019

Accepted: 20 May 2019

Publish: 01 Nov 2020

\section{Keywords:}

Well-being, Questionnaire, Mental health, Validity, Reliability

\begin{abstract}
A B S T R A C T
Background: This study aimed to develop and validate a well-being questionnaire based on the wisdom of Nahj al-Balagha.

Methods: The method of this research was descriptive. Accordingly, based on a predefined psychological well-being model, 74 items were formulated and approved by three experts from the Nahj al-Balagha field. The statistical population of this study included all adults aged 20 to 50 years, in Tehran. Using a simple sampling method, 200 people were selected as the study sample. Also, the reliability of the questionnaire was calculated through the Cronbach alpha coefficient. The validity of the questionnaire was assessed in two ways: validity and construct validity. The correlation of the questionnaire with the Ryff questionnaire was obtained for the validity of the questionnaire, and a confirmatory factor analysis was used to evaluate the construct validity.

Results: The data were analyzed using the SPSS and Amos software. The results showed that the psychological well-being questionnaire had an appropriate internal consistency in the range of 0.62 to 0.85 for the subscales and 0.95 for the total scale. Also, the total score of the researchermade questionnaire was significantly correlated with the Ryff 53-item questionnaire, using the Pearson correlation coefficient. Moreover, the fitness indices obtained from confirmatory factor analysis showed a proper construct validity for the scale; most of the items had a factor load of above 30 .
\end{abstract}

Conclusion: The questionnaire indicated good psychometric properties for assessing psychological well-being in Iranian society.

\footnotetext{
* Corresponding Author:

Samaneh Najarpourian, PhD.

Address: Department of Counseling, Faculty of Humanities, University of Hormozgan, Bandar Abbas, Iran.

Phone: +98 (917) 7314044

E-mail:najarpourian@hormozgan.ac
} 


\section{Introduction}

ealth is a comprehensive state of physical, psychological, and social $\mathbf{H}$ well-being not just the absence of symptoms [1]. In the history of madness and mental illness, mental health is defined in two common ways: the absence of mental illness and a wellbeing state. Psychological well-being is one of the subcategories of positive psychology. Despite the DSM system, Martin Seligman, as the founder of positive psychology, proposes character strengths and virtues, which include six virtues: wisdom, love, transcendence, moderation, justice, and courage [2].

Psychological well-being is a general concept that includes a pleasant emotional experience, low levels of negative mood, and high life satisfaction [3]. To date, some models of well-being are being developed, such as the Jahoda model, the Diner mental/psychological wellbeing model, the Ryff six-factor psychological well-being model, and the theory of self-determination by Deci and Ryan. Jahoda acknowledged that mental health is beyond a disorder. His explanation also includes mental health features, such as self-respect (self-respect, self-esteem, and self-interest), self-actualization, integrity (resistance to stress), independence, the perception of reality, and compatibility. Besides, in terms of the Ryff model, the psychological well-being components include self-acceptance, autonomy, environmental mastery, personal growth, positive relationships with others, and life purpose. However, the model of Ryan and Deci consists of three components: autonomy, competence, and connectivity. Finally, the mental/psychological wellbeing model of Diner is a general concept derived from a person's cognitive and emotional perception throughout life and has two cognitive and emotional components [4]. Therefore, none of the previous well-being theories have focused on spirituality and religion, while research literature has shown that religiosity is linked to positive health outcomes [5]. Also, studies confirm the positive relationship between religious practices and mental health [6]. On the other hand, most religions that have lasted for thousands of years in the world provide comprehensive and reliable theories and notions [7].

With this knowledge, Nahj al-Balagha is one of the main and most important sources of Islam, and consistent with nature, intellect, consciousness, and human emotions [8]. Nahj al-Balagha contains mental health messages and recommendations that fully meet wellknown criteria in this field [3]. For example, Rahim- ian has shown that the training guidelines from Nahj al-Balagha can effectively improve individual mental health [9]. After reviewing the Nahj al-Balagha's wisdom pearls, Mirzai et al. identified 10 psychological well-being components, including thanksgiving, hope, satisfaction in life, skill, patience, courage, freedom, trust, certainty, and knowledge [10]. These components are briefly explained as follows:

1. According to the words of Imam Ali (as), one of the characteristics of a healthy man is "thanksgiving" (Wisdom, 333) [11].

2. Another feature of a healthy person is "hope", which increases the effort to achieve the goals, as well as resistance to major challenges (Wisdom, 386, 156) [11].

3. Another characteristic of a healthy person is life satisfaction. A person who is happy with his life and does not feel sorry for what he has lost in the past (Wisdom, $439,228)[11]$.

4.In the light of God's obedience, the healthy people acquire their "sense of competence" and try to acquire knowledge and awareness (Wisdom, 81, 94) and perform valuable work (Wisdom, 94), and can control themselves well (Wisdom, 449) [11].

5. "Patience" is one of the main features of healthy people. This feature enhances the people's patience to cope with hardships and problems (Wisdom, 211), and evacuates their grudge and jealousy by forgiveness. Thus, people show appropriate responses to inappropriate actions (Wisdom, 178, 218) [11].

6. A healthy person is brave and does not withdraw when he does a hard and valuable job (Wisdom, 175) [11].

7. Healthy people are not greedy because of "freedom" from the constraints of the world (Wisdom, 228). Therefore, they do not lose their sense of satisfaction because of life limitations (Wisdom, 429) [11].

8. A healthy person is patient and hopeful with "confidence in the promises of God" (Wisdom, 135). Confidence in God will distract the person from greed (Wisdom 267, 300, 356, 359) [11].

9. Certainty is another feature of a healthy person (Wisdom, 147), and results in contentment (Wisdom, 349), which makes peace and life satisfaction (Wisdom, 371) [11]. 
10. The last component of psychological well-being is the "knowledge of the creator" (Sermon, 165), which is along with a transcending sense of humility to God (Wisdom, 333) [11].

Concerning the previous discussion, Islam's teaching seems to have provided its followers with the means and the right way of life and explained everything necessary for human perfection [12]. However, there is no psychological well-being scale based on religious sources and especially Nahj al-Balagha. Also, Iranian culture is linked to Islamic culture, and the research review shows that the issue of mental health is highly emphasized in Nahj al-Balagha. Thus, it seems necessary to develop an appropriate scale to assess psychological well-being from the perspective of Nahj al-Balagha. Therefore, the present study aimed to develop and validate a psychological well-being questionnaire based on the approaches of Nahj al-Balagha.

\section{Methods}

\section{Study design}

Based on the number of latent variables, the minimum sample size was determined for the confirmatory factor analysis (CFA) and the structural equation modeling. According to a rule (20 cases per factor/latent variable), the study sample size was estimated as 200 , because the researcher-made questionnaire was constructed based on the predesigned psychological well-being of 10 factors. The study samples were selected using the convenience sampling method from all male and female adults aged 20 and 50 years, in Tehran. Then, the researcher-made questionnaire was electronically provided to individuals. The questionnaire was answered by about 200 people.

\section{Procedures}

The questionnaire items were developed and then confirmed by three psychologists, in the development and validation phase of the questionnaire. The psychologists confirmed the items based on the Mirzaie et al. model of psychological well-being [10], which included 10 components, such as thanksgiving, hopefulness, life satisfaction, skill, patience, courage, freedom, trust, certainty, and knowledge. Also, the questionnaire was administered along with the Ryff psychological well-being questionnaire in 100 cases and then in 200 cases to evaluate the questionnaire's criterion validity. Calculating the internal consistency, the Cronbach alpha coefficient was used to investigate the questionnaire's reliability. Moreover, the questionnaire's validity was assessed us- ing both the criterion and the validity of the construct. The correlation between the overall scale and subscale scores and the Ryff scale and its subscales was examined in the criterion validity. Next, CFA was used to determine the validity of the questionnaire and confirm the proposed factor structure. The CFA was used because this method provides a predesigned model based on the theory and previous studies. So that the number of factors in the model was previously predicted by the researcher.

Confirmatory methods (hypothesis testing) determine whether data are consistent with a certain factor structure given in the hypothesis. However, factors are discovered rather than predefined in the exploratory factor analysis [13]. Since the factors of the psychological well-being model have already been identified in this research, CFA was used to examine the proposed factor structure. The items were scored on a 6-point Likert scale to analyze the obtained data. So, the questionnaire data were entered into SPSS v. 21 and the results were prepared as statistical tables. Then, CFA was used to confirm the factors, in Amos software v. 16.

\section{Measures}

The researcher-made psychological well-being questionnaire is a scale based on Nahj al-Balagha's approaches. This questionnaire includes 74 items scored on a 6-point Likert scale (completely agree, agree, no comment, disagree, and completely disagree). Also, the items $12,13,14,15,18,19,24,25,35,39,67$, and 69 are scored reversely. The questionnaire consists of 10 subscales of competence (questions 1-8), hopefulness (9$11)$, freedom (12-20), the satisfaction of life (21-24), trust (25-41), courage (42-48), patience (49-53), thanksgiving (54-61), knowledge (62-65), and certainty (66-74).

The Ryff psychological well-being questionnaire contains 84 items and 6 subscales, including self-acceptance, autonomy, the mastery of the environment, personal growth, positive relationships with others, and life purpose. This questionnaire is scored on a 6-point Likert scale (totally agree, agree, somewhat agree, somewhat disagree, disagree, totally disagree). Initially, Ryff developed the questionnaire's first version with 120 items, in 1995. Then, a shorter version was made in the following years, based on some studies. But Ryff believes that the 84-item version has a greater ability than other versions to determine individuals' psychological wellbeing. In the 84-items version, the measurement of each factor requires 14 items. Various studies have examined this questionnaire's psychometric properties [14]. 
Bayani et al. examined the validity and reliability of the 84-item version, in a sample of 145 people, in Iran. The results of the test-retest method showed the reliability coefficients of $0.82,0.71,0.78,0.77,0.78,0.77$, and 0.77 for the total scale, self-acceptance, autonomy, environmental mastery, personal growth, positive relationships with others, and purpose in life subscales, respectively [15]. Moreover, we calculated the correlations between the score of the scale and the scores of the life satisfaction scale, the Oxford happiness questionnaire, and the self-esteem scale of Rosenberg to assess the validity; the obtained correlation coefficients were $0.47,0.58$, and 0.46 , respectively. Consequently, the questionnaire on the psychological well-being of the Ryff had the appropriate validity.

\section{Results}

A total number of 200 people took part in this study; $16.3 \%$ and $82.8 \%$ of participants were men and women, respectively. Out of the total participants, $18.7 \%$ had a diploma or lesser education, $41.4 \%$ had undergraduate education, $32.5 \%$ had an MSc, and $5.9 \%$ had a $\mathrm{PhD}$ degree. Also, $41.9 \%, 36.9 \%, 15.8 \%$, and $4.4 \%$ of participants were in the age range of 20 to 30 years, 30 to 40 years, 40 to 50 years, and over 50 years, respectively. Furthermore, $65.5 \%$ and $33.5 \%$ of the participants were married and single, respectively. Table 1 provides the descriptive statistics of the scores of variables, including mean, standard deviation, maximum, and minimum.
According to Table 1, the total $\mathrm{Mean} \pm \mathrm{SD}$ is $343.37 \pm 86.45$, the maximum score is 439 and the minimum score is 206 .

The Cronbach alpha coefficient was used to assess the reliability of the questionnaire by calculating internal consistency (Table 2). According to the result, the coefficients obtained for all components except the competency are above 0.70 , which represents a suitable reliability coefficient. The total scale has the highest coefficient, and then, the components of trust, certainty, courage, patience, thanksgiving, freedom, life satisfaction, hopefulness, and competence have the correct reliability, in the respective descending order. The correlation was also calculated between the total and the subscales scores of the developed questionnaire and the Ryff questionnaire to examine the convergent validity of the questionnaire; Table 3 presents the results.

Concerning Table 3 data, and taking into account the value of the validity coefficient and the meaning level of 0.01 , there was a significant correlation between the Ryff questionnaire scores and the psychological well-being questionnaire scores $(\mathrm{r}=0.54)$. Also, there was a significant correlation between the scores of the components of the Ryff and researcher-made questionnaires, including life satisfaction $(\mathrm{r}=0.57)$, hopefulness $(\mathrm{r}=0.50)$, courage $(\mathrm{r}=0.46)$, freedom $(\mathrm{r}=0.41)$, confidence $(\mathrm{r}=0.41)$, certainty $(\mathrm{r}=0.36)$, knowledge $(\mathrm{r}=0.33)$, and thanksgiving $(\mathrm{r}=0.27) \quad(\mathrm{P}=0.001)$. However, the correlation values

Table 1. Descriptive indices of psychological well-being and its components in Nahj al-Balagha

\begin{tabular}{|cccc}
\hline Component & Mean \pm SD & Max. & Min. \\
\hline Competence & $6.41 \pm 66.4$ & 48 & 26 \\
\hline Hopefulness & $1.15 \pm 49.2$ & 18 & 6 \\
\hline Freedom & $2.34 \pm 86.8$ & 54 & 13 \\
\hline Life satisfaction & $5.16 \pm 19.4$ & 24 & 6 \\
\hline Confidence & $3.82 \pm 97.11$ & 102 & 43 \\
\hline Courage & $33 \pm 31.6$ & 42 & 15 \\
\hline Patience & $9.21 \pm 48.5$ & 30 & 6 \\
\hline Thanksgiving & $7.42 \pm 5$ & 48 & 22 \\
\hline Knowledge & $8.19 \pm 74.3$ & 24 & 8 \\
\hline Certainty & $7.37 \pm 47.9$ & 54 & 14 \\
\hline
\end{tabular}


Table 2. Cronbach alpha of the psychological well-being questionnaire and its components

\begin{tabular}{|c|c|}
\hline Component & Cronbach $\alpha$ \\
\hline Competence & 0.62 \\
\hline Hopefulness & 0.73 \\
\hline Freedom & 0.77 \\
\hline Life satisfaction & 0.76 \\
\hline Confidence & 0.86 \\
\hline Courage & 0.81 \\
\hline Patience & 0.79 \\
\hline Thanksgiving & 0.77 \\
\hline Knowledge & 0.75 \\
\hline Certainty & 0.85 \\
\hline Total scale & 0.95 \\
\hline
\end{tabular}

IRA

were insignificant for patience and competence. Among all the subscales, life satisfaction, hopefulness, courage, confidence, freedom, and certainty had the highest validity coefficients with the subscale of environmental mastery $(0.57,0.55,0.50,0.46,0.46$, and 0.44 , respectively). Besides, the knowledge subscale had the highest value of the validity coefficient with the personal growth subscale ( $\mathrm{r}=0.43$ ). Also, the self-acceptance component had the highest validity coefficients with the subscales of patience $(\mathrm{r}=0.38)$ and thanksgiving $(\mathrm{r}=0.35)$.

The CFA was used to determine the questionnaire's factor structure. Tables 4 and 5 present the results of the model fitting and the factor loading of items on each component. Before carrying out the CFA, we examined the assumptions for using this method, including missing

Table 3. Correlation coefficients between the scales and subscales' scores of the Ryff and the researcher-made psychological well-being questionnaires

\begin{tabular}{|c|c|c|c|c|c|c|c|c|c|c|c|}
\hline $\begin{array}{c}\text { Compo- } \\
\text { nents }\end{array}$ & $\begin{array}{l}\text { Total } \\
\text { Score }\end{array}$ & $\begin{array}{c}\text { life } \\
\text { Satis- } \\
\text { faction }\end{array}$ & $\begin{array}{l}\text { Hope- } \\
\text { fulness }\end{array}$ & $\begin{array}{l}\text { Cour- } \\
\text { age }\end{array}$ & $\begin{array}{l}\text { Free- } \\
\text { dom }\end{array}$ & $\begin{array}{l}\text { Confi- } \\
\text { dence }\end{array}$ & $\begin{array}{l}\text { Cer- } \\
\text { tainty }\end{array}$ & $\begin{array}{l}\text { Knowl- } \\
\text { edge }\end{array}$ & $\begin{array}{c}\text { Thanks- } \\
\text { giving }\end{array}$ & $\begin{array}{l}\text { Pa- } \\
\text { tience }\end{array}$ & $\begin{array}{c}\text { Compe- } \\
\text { tence }\end{array}$ \\
\hline $\begin{array}{l}\text { Ryff psy- } \\
\text { chological } \\
\text { well-being }\end{array}$ & $0.54^{* *}$ & $0.57^{* *}$ & $0.50^{* *}$ & $0.46^{* *}$ & $0.41^{* *}$ & $0.41 * *$ & $0.36^{* *}$ & $0.32^{* *}$ & $0.26^{* *}$ & 0.19 & 0.14 \\
\hline $\begin{array}{l}\text { Self-ac- } \\
\text { ceptance }\end{array}$ & & $0.57^{* *}$ & $0.48^{* *}$ & $0.47^{* *}$ & $0.46^{* *}$ & $0.36 * *$ & $0.40^{* *}$ & $0.37^{* *}$ & $0.34^{* *}$ & $0.37^{* *}$ & 0.11 \\
\hline $\begin{array}{l}\text { Positive } \\
\text { relation- } \\
\text { ships with } \\
\text { others }\end{array}$ & & $0.27^{* *}$ & 0.14 & $0.31^{* *}$ & $0.38^{* *}$ & 0.18 & $0.26^{* *}$ & $0.27^{* *}$ & 0.20 & 0.21 & 0.05 \\
\hline Autonomy & & $0.45^{* *}$ & $0.35^{* *}$ & $0.38^{* *}$ & $0.31^{* *}$ & $0.31^{* *}$ & $0.23^{* *}$ & $0.35^{* *}$ & 0.20 & 0.13 & 0.02 \\
\hline $\begin{array}{l}\text { Environ- } \\
\text { mental } \\
\text { mastery }\end{array}$ & & $0.57^{* *}$ & $0.55^{* *}$ & $0.50^{* *}$ & $0.48^{* *}$ & $0.46^{* *}$ & $0.44^{* *}$ & $0.38^{* *}$ & $0.32^{* *}$ & $0.27^{* *}$ & 0.11 \\
\hline $\begin{array}{l}\text { Purpose } \\
\text { in life }\end{array}$ & & $0.54^{* *}$ & $0.51^{* *}$ & $0.49^{* *}$ & $0.38^{* *}$ & $0.43^{* *}$ & $0.41^{* *}$ & $0.34^{* *}$ & $0.28^{* *}$ & $0.25^{* *}$ & 0.05 \\
\hline $\begin{array}{l}\text { Personal } \\
\text { growth }\end{array}$ & & $0.54^{* *}$ & $0.43^{* *}$ & $0.41^{* *}$ & $0.41^{* *}$ & $0.43^{* *}$ & $0.43^{* *}$ & $0.40^{* *}$ & $0.31^{* *}$ & $0.25^{* *}$ & 0.19 \\
\hline
\end{tabular}


Table 4. The CFA fitness indices of Nahj al-Balagha's subjective well-being questionnaire

\begin{tabular}{ccc}
\hline Fitness Indices & Values \\
\hline$\chi^{2}$ & 5138.866 \\
DF & $0.001 \geq$ \\
$\chi^{2} / \mathrm{df}$ & 2583 \\
GFI & 1.98 \\
AGFI & 0.88 \\
NFI & 0.87 \\
CFI & 0.83 \\
IFI & 0.90 \\
TLI & 0.90 \\
RMSEA & 0.89 \\
\hline
\end{tabular}

data, outliers, normality, and multiple linear analyzes, which were approved for all assumptions.

The fitness indices' values showed a modest fit for this model (Table 4). The CFA resulted in the values of 0.07 , $0.91,0.88,0.87,0.83,0.90$, and 0.89 for the indices of RMSEA, CFI, GFI, AGFI, NFI, IFI, and TLI, respectively. Therefore, the model benefits from moderate fitness.

The majority of the items were loaded with a standard factor of greater than 0.30 (Table 5), when carrying out the CFA for the Nahj al-Balagha mental health questionnaire. In other words, the grade points were significantly related to their factors $(\mathrm{P}<0.001)$, also, items with a factor loading of below 0.30 were excluded from the questionnaire. The excluded items included items 5 and 6 from the value component, item 16 from the freedom component, item 24 from the life satisfaction component, items 35 and 39 from the feeling of assurance component, and items 67 and 69 from the component of the certainty. Overall, the questionnaire factor analysis revealed that the questionnaire items account for about $59 \%$ of the total psychological well-being variance.

\section{Discussion}

According to the results, the researcher-made questionnaire is suitable for evaluating psychological well-being. Furthermore, CFA results show that this model is well fitted and most items have a high load. Most standard coefficients were above 0.30 and items below 0.30 were removed from the questionnaire. Overall, the questionnaire's factor structure analysis revealed that the questionnaire items explained about $59 \%$ of the total psychological well-being variance. Also, the observed factor structure was classified into 10 categories: thanksgiving, hope, life satisfaction, competence, patience, courage, freedom, trust, certainty, and knowledge. This factor structure has significant conceptual similarity with positive psychology and the theories of psychological well-being. So that the subscale of "life satisfaction" in this structure is in line with the Diner theory and the concept of "hopefulness" is concurrent to the concept of "hope" in the Snyder theory. Also, the subscales of "courage", "freedom", the "knowledge of the creator", and "thanksgiving" correspond to the concepts of "courage" (struggle, perseverance, and hard work), moreover, "moderation" (self-control), "transcendence", and "appreciation" are similar in Seligman's theory. On the other hand, positive features, such as patience, forgiveness, hope, and freedom, which are considered by other positivist theorists like Seligman, have a positive relationship with the subscale of "confidence". The other subscale in this structure is "certainty", meaning belief in the world, afterward, a major belief affects minor beliefs, such as belief in a just and unjust world. The more powerful this belief is, the weaker the level of mental health threats, such as anxiety, worry, depression, suicidal thoughts, and anger will be caused by ill-treatment and injustices brought to human beings by others [16]. Patience is an- 
Table 5. Subscales of the subjective well-being questionnaire based on the Nahj al-Balagha and the factor loading of the items related to each factor

\begin{tabular}{|c|c|c|c|c|c|c|c|c|c|c|}
\hline Factors & $\begin{array}{l}\text { Compe- } \\
\text { tence }\end{array}$ & Hopefulness & Freedom & $\begin{array}{l}\text { Life Satis- } \\
\text { faction }\end{array}$ & Confidence & Courage & Patience & $\begin{array}{l}\text { Thanks- } \\
\text { giving }\end{array}$ & Knowledge & Certainty \\
\hline Item 1 & 0.61 & & & & & & & & & \\
\hline Item 2 & 0.54 & & & & & & & & & \\
\hline Item 3 & 0.43 & & & & & & & & & \\
\hline Item 4 & 0.33 & & & & & & & & & \\
\hline Item 5 & 0.28 & & & & & & & & & \\
\hline Item 6 & 0.15 & & & & & & & & & \\
\hline Item 7 & 0.43 & & & & & & & & & \\
\hline Item 8 & 0.33 & & & & & & & & & \\
\hline Item 9 & & 0.88 & & & & & & & & \\
\hline Item 10 & & 0.81 & & & & & & & & \\
\hline Item 11 & & 0.51 & & & & & & & & \\
\hline Item 12 & & & 0.48 & & & & & & & \\
\hline Item 13 & & & 0.80 & & & & & & & \\
\hline Item 14 & & & 0.82 & & & & & & & \\
\hline Item 15 & & & 0.72 & & & & & & & \\
\hline $\begin{array}{l}\text { Item } \\
16\end{array}$ & & & 0.26 & & & & & & & \\
\hline Item 17 & & & 0.22 & & & & & & & \\
\hline Item 18 & & & 0.42 & & & & & & & \\
\hline Item 19 & & & 0.58 & & & & & & & \\
\hline Item 20 & & & 0.34 & & & & & & & \\
\hline Item 21 & & & & 0.59 & & & & & & \\
\hline Item 22 & & & & 0.72 & & & & & & \\
\hline Item 23 & & & & 0.87 & & & & & & \\
\hline Item 24 & & & & 0.29 & & & & & & \\
\hline Item 25 & & & & & 0.25 & & & & & \\
\hline Item 26 & & & & & 0.51 & & & & & \\
\hline Item 27 & & & & & 0.69 & & & & & \\
\hline Item 28 & & & & & 0.74 & & & & & \\
\hline Item 29 & & & & & 0.72 & & & & & \\
\hline Item 30 & & & & & 0.59 & & & & & \\
\hline Item 31 & & & & & 0.60 & & & & & \\
\hline Item 32 & & & & & 0.79 & & & & & \\
\hline Item 33 & & & & & 0.67 & & & & & \\
\hline Item 34 & & & & & 0.53 & & & & & \\
\hline
\end{tabular}




\begin{tabular}{|c|c|c|c|c|c|c|c|c|c|c|}
\hline Factors & $\begin{array}{l}\text { Compe- } \\
\text { tence }\end{array}$ & Hopefulness & Freedom & $\begin{array}{l}\text { Life Satis- } \\
\text { faction }\end{array}$ & Confidence & Courage & Patience & $\begin{array}{l}\text { Thanks- } \\
\text { giving }\end{array}$ & Knowledge & Certainty \\
\hline Item 35 & & & & & 0.20 & & & & & \\
\hline Item 36 & & & & & 0.53 & & & & & \\
\hline Item 37 & & & & & 0.40 & & & & & \\
\hline Item 38 & & & & & 0.52 & & & & & \\
\hline Item 39 & & & & & 0.12 & & & & & \\
\hline Item 40 & & & & & 0.74 & & & & & \\
\hline Item 41 & & & & & 0.78 & & & & & \\
\hline Item 42 & & & & & & 0.78 & & & & \\
\hline Item 43 & & & & & & 0.54 & & & & \\
\hline Item 44 & & & & & & 0.62 & & & & \\
\hline Item 45 & & & & & & 0.79 & & & & \\
\hline Item 46 & & & & & & 0.59 & & & & \\
\hline Item 47 & & & & & & 0.42 & & & & \\
\hline Item 48 & & & & & & 0.51 & & & & \\
\hline Item 49 & & & & & & & 0.71 & & & \\
\hline Item 50 & & & & & & & 0.69 & & & \\
\hline Item 51 & & & & & & & 0.57 & & & \\
\hline Item 52 & & & & & & & 0.72 & & & \\
\hline Item 53 & & & & & & & 0.60 & & & \\
\hline Item 54 & & & & & & & & 0.62 & & \\
\hline Item 55 & & & & & & & & 0.54 & & \\
\hline Item 56 & & & & & & & & 0.71 & & \\
\hline Item 57 & & & & & & & & 0.68 & & \\
\hline Item 58 & & & & & & & & 0.35 & & \\
\hline Item 59 & & & & & & & & 0.31 & & \\
\hline Item 60 & & & & & & & & 0.66 & & \\
\hline Item 61 & & & & & & & & 0.77 & & \\
\hline Item 62 & & & & & & & & & 0.73 & \\
\hline Item 63 & & & & & & & & & 0.52 & \\
\hline Item 64 & & & & & & & & & 0.69 & \\
\hline Item 65 & & & & & & & & & 0.69 & \\
\hline
\end{tabular}




\begin{tabular}{|c|c|c|c|c|c|c|c|c|c|c|}
\hline Factors & $\begin{array}{l}\text { Compe- } \\
\text { tence }\end{array}$ & Hopefulness & Freedom & $\begin{array}{l}\text { Life Satis- } \\
\text { faction }\end{array}$ & Confidence & Courage & Patience & $\begin{array}{l}\text { Thanks- } \\
\text { giving }\end{array}$ & Knowledge & Certainty \\
\hline Item 66 & & & & & & & & & & 0.69 \\
\hline Item 67 & & & & & & & & & & 0.23 \\
\hline Item 68 & & & & & & & & & & 0.51 \\
\hline Item 69 & & & & & & & & & & 0.23 \\
\hline Item 70 & & & & & & & & & & 0.75 \\
\hline Item 71 & & & & & & & & & & 0.87 \\
\hline Item 72 & & & & & & & & & & 0.78 \\
\hline Item 73 & & & & & & & & & & 0.79 \\
\hline Item 74 & & & & & & & & & & 0.84 \\
\hline $\begin{array}{l}\text { Total } \\
\text { ex- } \\
\text { plained } \\
\text { vari- } \\
\text { ance }\end{array}$ & & 59 & & & & & & & & \\
\hline
\end{tabular}

other factor that includes subcategories, such as forgiveness and the lack of envy, and is consistent with the Seligman theory of forgiveness and the meaning of jealousy in psychology. Finally, the subscales of competence that include subcategories, such as "acquire knowledge and science", "having great goals", "self-control", "worship", and "doing great and worthy work" are consistent with the "concepts of self-control", "sense of purposefulness", and the "love of learning" in the Seligman theory.

\section{Conclusion}

Given the need for an objective tool to assess psychological well-being, the current questionnaire focusing on Nahj alBalagha can be a useful tool for assessing adult mental health status and psychological well-being. This questionnaire is not only suitable for evaluating psychological well-being, but also an effective measure of psychological well-being and mental health for research. Also, this questionnaire can be used in clinical and research situations at a practical level. However, along with the results, some limitations have accompanied the present study and the sampling method. The most important limitations include the implementation of research on a sample of Tehran citizens and the use of selfreport questionnaires. Accordingly, it is recommended to use this questionnaire in different populations. Besides, it is suggested to repeat the validity assessment of this questionnaire with other related questionnaires to increase the reliability and validity of this questionnaire. The use of the other methods of information collection, especially in a qualitative manner, including interviews, can partially resolve the shortcomings in the self-report questionnaire.

\section{Ethical Considerations}

\section{Compliance with ethical guidelines}

The research plan was approved by the Ethics Committee of the University of Hormozgan (Code: 9832, on May 22, 2017).

\section{Funding}

This research is extracted from a $\mathrm{PhD}$. dissertation of first author, Department of Counseling, Faculty of Humanities, University of Hormozgan, Bandar Abbas.

\section{Authors' contributions}

All authors equally contributed to preparing this article.

\section{Conflict of interest}

The authors declared no conflicts of interest.

\section{Acknowledgments}

The authors appreciate the collaboration of all Nahj alBalagha and psychology professors and experts, as well as all others who participated in this research in the development and validation phases of the psychological well-being questionnaire for Nahj al-Balagha. 


\section{References}

[1] Rahiminezhad A, Rahimijafari M, Salamati P. [The relationship of identity styles and psychological, social and emotional well-beings: The mediating role of commitment and accepting religious identity (Persian)]. Appl Psychol Res Quart. 2016; 6(4):95-112. [DOI:10.22059/JAPR.2016.57966]

[2] Seligman M. Authentic happiness: Using the new positive psychology to realize potential for lasting fulfillment. [Tabrizi M, Karimi R, Niloofari A, Persian trans.]. Tehran: Denjeh Publication; 2009.

[3] Fathi Mozafari R, Alizade G. [The study of Ryff's factor scale of psychological well-being in Nahj al-Balagha (Persian)]. J Nahjolbalaghe Res. 2015; 4(14):55-72. [DOI:10.22084/NAHJ.2016.1574]

[4] Kheiri M, Emami Sigaroudi A, Faramanber RA, AtrkarRoushan Z. [Subjective well-being and related factor among students of Guilan University of Medical Sciences (GUMS)(Persian)]. Iran J Health Educ Health Promot. 2014; 2(1):27-36. http://journal. ihepsa.ir $/$ browse.php?a_id=113\&sid=1\&slc_lang=en

[5] Baker JO, Stroope S, Walker MH. Secularity, religiosity, and health: Physical and mental health differences between atheists, agnostics, and nonaffiliated theists compared to religiously affiliated individuals. Soc Sci Res. 2018; 75:44-57. [DOI:10.1016/j. ssresearch.2018.07.003] [PMID]

[6] You S, Yoo JE, Koh Y. Religious practices and mental health outcomes among Korean adults. Pers Individ Dif. 2019; 142:7-12. [DOI:10.1016/j.paid.2019.01.026]

[7] Koenig HG. Religion, spirituality, and health: The research and clinical implications. ISRN Psychiatry. 2012; 2012:278730. [DOI:10.5402/2012/278730] [PMID] [PMCID]

[8] Olianasab SZ. Nahj al-Balagha: Herald of health. J Res Religion \& Health. 2016; 2(4):1-4. http:/ /journals.sbmu.ac.ir/en-jrrh/article/view/15472

[9] Rahimian Bogar E. [The effect of Nahjolbalagha training on mental health of university students (Persian)]. J Nahjolbalaghe Res. 2013; 1(1):75-84. https:/ / nab.basu.ac.ir/article_421.html

[10] Mirzaei S, Najarpourian S, Naeimi E, Samavi W. [Developing (formulating) a model of psychological well-being based on the approaches of Nahj al-Balaghah (Persian)]. Counsel Cult Psychother. 2018; (9)34:1-26. [DOI:10.22054/QCCPC.2018.31645.1817]

[11] Imam Ali. [Nahj al-Balaghe (Persian)]. Tehran: Payam Edalat; 2005.

[12] Ghasemi S. [Watch out for mental health with an attitude to the teachings of religion and sin (pbuh) (Persian)]. Qom: Imam Khomeini Educational and Research Institute; 2009.

[13] Sobhanifar Y, Akhavan Kharozian M. Factor analysis of structural and multivariate equations modeling using SPSS- SAS HLM - LISREL (Persian)]. Tehran: Imam Sadiq University; 2012.

[14] Michaeli Manee F. [The study of Ryff psychological well-being scale factorial structure between Urmia university students (Persian)]. J Modern Psychol Res. 2010; 5(18):143-65. https://psychologyj.tabrizu.ac.ir/article_4209.html?lang=en

[15] Bayani AA, Koocheky AM, Bayani A. [Reliability and validity of Ryff's psychological well-being scales (Persian)]. Iran J Psychiatry Clin Psychol. 2008; 14(2):146-51. http://ijpcp.iums.ac.ir/ browse.php?a_id $=464 \&$ sid $=1 \&$ slc_lang $=$ en
[16] Golparvar M, Estabraghi E, Javadian Z. [Modifying effect of believing in Day of Judgment on the relation between believing in just and unjust world and psychological well-being (Persian)]. Stud Islam Psychol. 2012; 6(11):75-94. http://islamicpsy.rihu.ac.ir/article_1056.html 